Egyptian Journal of Rabbit Science, 31(2): 171-198 (2021)

\title{
INFLUENCE OF PAPAYA LEAVES AND THEIR EXTRACT SUPPLEMENTATION ON GROWING RABBIT PERFORMANCE, PHYSIOLOGICAL TRAITS, IMMUNE RESPONSES AND OXIDATIVE ENZYME STATUS.
}

\author{
Fatma T.F.Abd-ELGhany ${ }^{1}$; M.M.EL-Gebali ${ }^{1}$ and Ghada.G. Gad ${ }^{2}$ \\ ${ }^{1}$ Animal Production Research Institute, Agricultural Research Center, Ministry \\ of Agriculture, Dokki, Giza, Egypt. \\ ${ }^{2}$ Poultry Production Department, Faculty of Agriculture, Ain Shams University, \\ Cairo,Egypt.e.mail:ghadagad2015@gmail.com
}

\begin{abstract}
The present study aimed to determine the effects of using different levels of papaya leaves (PL) and papaya leaves extract (PLE) on productive performance, some blood constituents, oxidative enzyme status, carcass traits, immune response, digestibility coefficients and economic efficiency of weaned New Zealand White rabbits (NZW). Eighty four weaned New Zealand White rabbits (NZW) aged 35 days and weighed $564 \mathrm{~g} \pm 3.40$ were distributed randomly into seven groups $(12$ each). The experimental diets contained different levels of papaya leaves and papaya leaves extract ( 0.0 controls $(C), 1,2$ and $3 \%$ papaya leaves or papaya leaves extract, respectively. The experiment was lasted for 8 weeks.
\end{abstract}

The obtained results indicated that: The final live body weight, total weight gain and performance index were significantly $\quad(P<0.05)$ improved in the treated groups. Digestibility coefficient and nutritive values were significantly improved for rabbits fed diet contained $P L$ and PLE compared to those fed the control diet.
There were significant increases detected for plasma total protein, albumin and globulin while blood plasma cholesterol, LDL and total lipids were significantly decreased by increasing PL and PLE inclusion level compared to control groups. Liver function as AST and ALT activity were not affected by dietary supplementation. Moreover the concentrations of IgG and IgM of rabbits were higher for rabbit supplemented with PL and PLE than the control group. GPX, SOD and CAT were significantly improved by dietary PL and PLE. The best economic efficiency had been recorded with rabbits fed 3\% PLE inclusion followed by rabbits received $2 \%$ and $1 \%$ treatment of PLE, respectively. It is concluded that supplemental papaya leaves extract at the rate of $3 \%$ of the diet improved feed conversion ratio, nutrients digestibility, immunity, and economic efficiency of the NZW rabbits.

Keywords: Papaya leaves, growth performance, digestibility, rabbits and diet. 


\section{INTRODUCTION}

Papaya, a juicy and tasty fruit, belonging to family Caricaceae is scientifically known as Carica papaya Linn. It is grown in various parts of the world, including Egypt, India, America and Europe. It is commonly known as Papaya melon tree or Pawpaw, the leaves are large, 50-70 cm in diameter, deeply palmately lobed, with seven lobes. Papaya leaves are rich source of the proteolytic enzymes papain and chymopapain which have protein digesting properties and are useful in controlling digestive problems and intestinal worms (Burkill, 1985). Also, papaya leaves and their extract contain carotene, provitamin A, which serves as many as 18-50 IU and can be used as a source of natural Xanthophyll. Papaya leaves contain vitamin C, vitamin E, calcium, phosphorous and iron. Beside that the leaves contain $20.88 \%$ crude protein, $0.99 \%$ calcium, $0.47 \%$ phosphorous and $2912 \mathrm{kcal} / \mathrm{kg}$ gross energy (Mahendra and Nikhil, 2016).

Recent numerous research aimed to use of natural growth promoters to enhance feed utilization, growth performance and immune responses of poultry (El-Kholy et al., 2008; Zeedan et al., 2009 and Sorwar et al., ,2016). Moreover antioxidant supplements in animal diets present the advantage that living animals may efficiently distribute the compounds throughout the tissues, and the resulting enriched animal production ensures tolerable amounts for humans (Bou et al., 2009; Laudadio et al., 2015). Previous studies have indicated that a long-term dietary supplementation with a natural Papaya leaves extract leads to an antioxidant effect in pork, enhancing its oxidative status, (Rossi et al., 2013).

Thus, the aim of the study was to investigate the effect of papaya leaves and their extract as feed additive on nutrients digestibility, immunity, performance, some blood constituents and economic efficiency of growing rabbits.

\section{MATERIALS AND METHODS}

\section{Animals, diet, and experimental design:-}

The experiment aimed to evaluate the growth promoting efficacy supplementation growing rabbit diets with papaya leaves and their extract by1, 2, 3\%. Eighty Four weaned New Zealand White rabbits (NZW) aged 35 days and weighed $564 \mathrm{~g} \pm 3.40$ were equally and randomly divided into seven groups (12 in each one). Rabbits were housed in galvanized metal rabbit battery cages supplied with separated feeders. Diets were offered in pellets form ad libtum and fresh clean water was available all times from automatic nipple drinkers. Feed intake and live weight were recorded weekly, feed conversion 
ratio and relative growth rate were calculated. All animals were kept under the same managements and hygienic conditions.

The experimental diets supplemented with different levels of papaya leaves or papaya leaves extract ( 0.0 control (C), 1, 2 and 3\%), respectively. All diets were iso-protein and iso-digestible energy, and to satisfy the nutrient requirements according to Agriculture Ministry Decree (1996) recommendations. The experiment was lasted for 8 weeks. Composition and calculated analysis of the experimental main diet is presented in Table (1).

\section{Preparation of plant extract}

Mature and disease free papaya leaves were obtained from pawpaw trees. For the preparation of extract, 1,2, and 3 gram Leaves soaked in $100 \mathrm{ml}$ distilled water for 1,2, and 3\% (PLE) respectively, and macerated for 6 hours. At the end of 6 hours, the extract was filtered through Whatman No.1 filter paper (Mrinal and Bhushan, 2017).

\section{Nutrients digestibility and carcass characteristics}

At the end of the experimental period, digestibility trail was carried out using three rabbits from each treatment. Feces were collected daily, weighed and dried at $60-70{ }^{\circ} \mathrm{C}$ for 24 hours, finely ground and stored for chemical analysis. Data of quantities and chemical analysis of feed and feces were used to calculate the nutrients digestion coefficients and the nutritive values of the dietary treatments, as described by Cheeke et al. (1982). Carcass traits were studied; relative weight of giblets percentages (heart, liver and kidney) and dressing percentage was calculated according to Steven et al., (1981). Boneless meat of breast and thigh muscle was determined according to A.O.A.C (2000).

\section{Biochemical parameters}

Blood samples were collected during slaughtering in heparinized tubes. Blood plasma were separated by centrifugation at $4000 \mathrm{rpm}$ for 10 minutes, and then frozen at $-20 \mathrm{C}$ until analysis. Commercial kits were used to determine plasma total protein, albumin, Aspartate transaminase (AST), alanine transaminase (ALT), cholesterol, LDL, HDL and total lipids. Plasma immunoglobulin, IgG and IgM were detected.

\section{Histology examination}

The liver specimens were taken for histological study, fixed in $10 \%$ neutral-buffered formalin, dehydrated in a graded alcohol series $(70 \%, 90 \%$, absolute ethanol), cleared with methyl benzoate and embedded in paraffin wax. Sections of $5 \mu \mathrm{m}$ were cut, fixed on glass slides and stained with hematoxylin and eosin for light microscopic examination (Bancroft et al., 1996; Oloruntola et al., 2017). Stained sections were examined by light microscope and photographed using a digital camera. 
Table 1. Composition and calculated analysis of the experimental diets for growing rabbits.

\begin{tabular}{|c|c|c|}
\hline Ingredients & & $\%$ \\
\hline Clover hay $(12 \% \mathrm{CP})$ & & 30.00 \\
\hline Barely & & 29.00 \\
\hline Yellow Corn & corn & 10.00 \\
\hline Soybean meal (44\%CP) & & 18.00 \\
\hline Wheat bran & & 8.00 \\
\hline Molasses & & 3.00 \\
\hline DL-Methionine & & 0.10 \\
\hline Vit. \& Min. mix.* & & 0.40 \\
\hline Salt & & 0.50 \\
\hline Limestone & & 1.00 \\
\hline Total & & 100 \\
\hline \multicolumn{3}{|l|}{ Ration Calculated analysis 1} \\
\hline Crude protein $\%$ & & 17.02 \\
\hline Digestible energy $(\mathrm{Kcal} / \mathrm{Kg})$ & & 2500 \\
\hline $\mathrm{C} / \mathrm{P}$ ratio & & 147 \\
\hline Extract Ether \% & & 2.72 \\
\hline Crude fiber \% & & 13.25 \\
\hline $\mathrm{NDF} \%$ & $\mathrm{~m}$ & 37.63 \\
\hline $\mathrm{ADF} \%$ & $\mathrm{n}$ & 21.52 \\
\hline Hemicellulose & $\% 0$ & 16.11 \\
\hline Calcium & $\%$ & 1.10 \\
\hline Total Phosphorus \% & & 0.80 \\
\hline Methionine & $\%$ & 0.36 \\
\hline TSAA & & 0.61 \\
\hline Lysine \% & & 0.75 \\
\hline \multicolumn{3}{|c|}{ 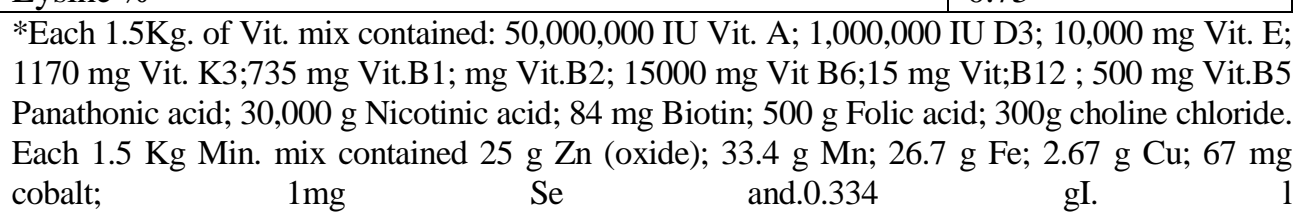 } \\
\hline
\end{tabular}

According to Feed Composition Tables for animal and poultry feedstuffs used in Egypt (2001) ,except values of DDGS, which were determined (Table 2). ${ }^{\text {Mno }}$ Calculated according to Cheeke (1987).

$\mathrm{m}_{\%} \mathrm{NDF}=28.924+0.657(\% \mathrm{CF})$

${ }^{\mathrm{n}} \% \mathrm{ADF}=9.432+0.912(\% \mathrm{CF})$

${ }^{\circ} \mathrm{Hemicellulose}=\% \mathrm{NDF}-\% \mathrm{ADF}$

\section{Cecum activities}

Samples of cecum contents were taken from slaughtered rabbits and used immediately for estimation of cecum $\mathrm{pH}$, cecum microflora (bacteria) Aerobic total count, Fecal coliforms, Escherichia coli count, Bacillus cereus, 
Enterobacter, Clostridium sp., Enterococcus, yeasts, Salmonella and Shigella. Another sample of cecum content was strained through four folds of gauze and divided into two portions. The first portion was used immediately for the estimation of ammonia nitrogen concentration. The second portion was preserved by addition of $1 \mathrm{ml} \mathrm{N} / 10 \mathrm{HCL}$ and $2 \mathrm{ml}$ orthophosphoric acid to each $2 \mathrm{ml}$ of cecum contents juice for determination total volatile fatty acids. The $\mathrm{pH}$ of the cecum contents was measured immediately by using a digital $\mathrm{pH}$ meter. The microbial contents were studied in their selective media, as described by Postage (1969) for Aerobic total bacterial counts and Difco (1989) for Fecal coliforms and E.coli, while, the methods described by Baired Parker (1962) and Kim and Goepfert (1971) were used for Enterococcus and Bacillus cereus, respectively and Difco (1989) for Enterobacter and Clostridium sp.; while the method described by Lodder (1952) was used for yeasts determination. Salmonella and Shigella were enumerated according to the methods described by AOAC (1998). Technique of colony forming unit (CFU) was adopted. Incubation took place at $30 \mathrm{oC}$ for 2-7 days. The ammonia nitrogen concentration was determined by applying method of Conway (1958). The total volatile fatty acids were determined by steam distillation of the distillate as mentioned by Eadie et al. (1967).

\section{Economic efficiency}

The economic efficiency of the experimental diets was calculated as the ratio between income (price of weight gain) and cost of feed consumed, calculated according to the price of the Egyptian market.

\section{Statistical analysis}

The data were analyzed using General Linear Models (GLM) procedure of SAS (2001). The statistical model was:

$$
\mathrm{Y}_{\mathrm{ij}}=\mu+\mathrm{T}_{\mathrm{i}}+\mathrm{e}_{\mathrm{ij}}
$$

Where: $\mathrm{Yij}=$ Any observation, $\mu=$ Overall mean, $\mathrm{Ti}=$ Effect of treatment, and $\mathrm{e}_{\mathrm{ij}}=$ Experimental error.

Variables having a significant F-test were compared using Duncan's multiple rang test (Duncan, 1955).

\section{RESULTS AND DISCUSSIN}

\section{Growth performance traits}

Results presented in Table 2 showed the effect of adding papaya leaves extract (PLE) and papaya leaves (PL) in diets for growing rabbits on growth 


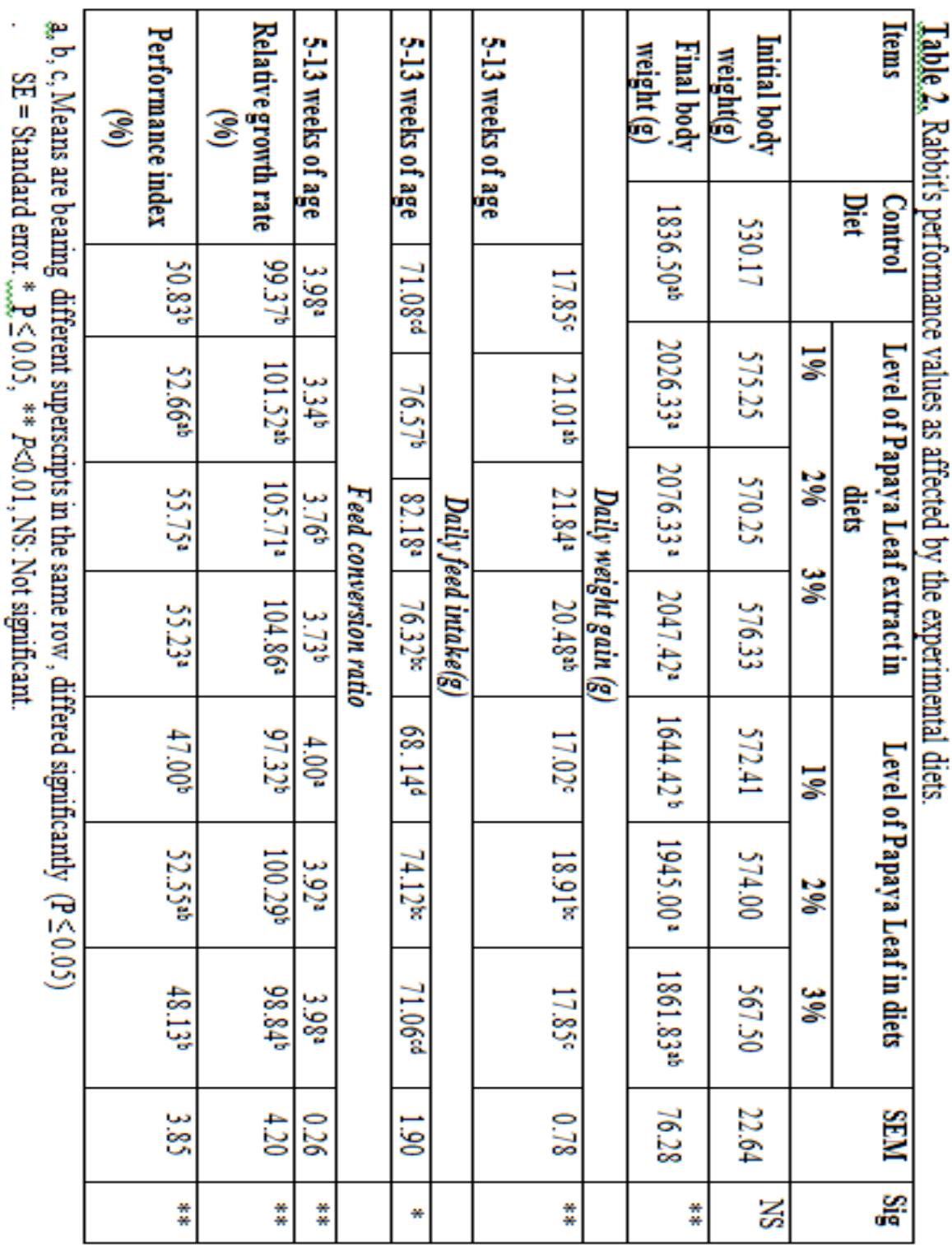




\section{USINGPAPAYALEAVES \& THEIR EXTRACT SUPPLEMENTATION IN RABBITS 177}

performance traits. It showed that final body weight and daily weight gain were significantly $(\mathrm{P}<0.01)$ higher in rabbits fed on PLE diets as compared to rabbits fed on control and PL diets. While, during 5-13 week of age period, there was no significant difference on daily weight gain between PL and control animals

The daily weight gain between 5-13 weeks of age was recorded to be 21.01, 21.84 and $20.48(\mathrm{~g})$ for rabbits fed on diets supplemented by $1,2,3 \%$, PLE respectively, when compared with rabbits fed on diets supplemented by PL ,17.02,18.91and 17.85, respectively. Total Feed conversion ratio was significantly $(\mathrm{P}<0.01)$ improved with rabbits fed PLE diets compared to other treatments. During the experimental period (5-13 weeks of age) 1\% PLE was the best value with $3.34 \mathrm{~kg}$ diet $/ \mathrm{kg}$ growth, comparing with control diet which recorded $3.98 \mathrm{~kg}$ diet $/ \mathrm{kg}$ growth. Although, feed intake did not significantly affected by dietary treatments throughout 5-13 weeks of age rabbit fed PLE diets recorded $76.57,82.18$ and 76.32 , respectively for 1,2 and $3 \%$ supplemented level comparing with control diet which recorded 71.08. Performance index and relative growth rate $(\%)$ increased significantly $(\mathrm{P}<0.0 .01)$ in rabbits fed on PLE diets compared to that fed on other diets. Rabbit fed on 2\% PLE supplemented diet had the highest relative growth rate with value 105.71 compared to other treatments without holding significant difference with other PLE diet groups. However, 2,and 3\% PLE groups showed the highest performance index values 55.75 and 55.23 comparing with other treatments with non-significant difference with 1\% PLE group and 2\% PL group with values 52.66 and 52.55 respectively, but with significantly $(\mathrm{P}<0.0 .01)$ difference with other groups. This result is confirmed by Nusrat et $a l$, (2015) who reported that Addition of papaya leaves extract improved the weight gain of broilers. These results are agreement with the findings of Ahmad (2005), Wanker et al. (2009) , Onyimonyi, et al. (2009) and Sorwar et al,(2016) who reported that the body weight gains and feed efficiency increased in treated groups with PL compared to non-treated control group. This trend could be ascribed to the high nutritional value in terms of protein and minerals/vitamins supplied by PL particularly when increased. It could also be attributed to the papain in the PL which aid protein digestion thus enhancing the release of free amino acids necessary to enhance growth. This improvement may be attributed to proteolytic enzyme of exogenous origin plays an important role in feed digestibility.

The improvement of digestibility coefficient values may be attributed to the potential beneficial effect of these additives PL and PLE on gastrointestinal tract micro-organisms and metabolites which be reflected on improving the digestibility of feed nutrients and conversions. Also, this improvement may be 
attributed to reduction in digesta viscosity, increases the diffusion rates of nutrients and enzymes enabling rabbits to digest and absorb more nutrients. Similar results were confirmed by Krishna et al. (2008), Zeedan et al. (2009) and El-Neney et al. (2013, 2015). Unigwe et al. (2014) reported that papain is an effective natural digestive aid which breaks down protein and cleanses the digestive tract.

\section{Digestibility coefficients and nutritive value of the diets}

Results in Table 3 indicated that apparent digestibility of DM and EE were not significantly affected by different treatments. On the other hand, digestibility of $\mathrm{CP}$ and $\mathrm{CF}$ were significantly $(\mathrm{P}<0.0 .01)$ affected. The best upon feeding rabbits on 3\% PLE supplemented diets which recorded (77.43 and 37.43) respectively compared to 3\% PL supplemented diet which recorded (74.89 and 33. 23) respectively and control diet which recorded (74.9 and $30.67)$ respectively. Also, digestibility coefficients of NFE significantly ( $\mathrm{P}<$ 0.001) increased with 2 and 3\% PLE supplemented diet which recorded (77.48 and 78.28) respectively compared to $3 \%$ PL diets which recorded 75.75 and control diet which recorded 75.89. That, digestibility of NFE did not differ significantly with PL diets compared to control diet. Nutritive values in terms of DCP and TDN were significantly $(\mathrm{P}<0.01)$ improved compared to the control. That, DCP was significantly improved with PLE diets which recorded 13.31 in $3 \%$ diet compared to the control diet which recorded 12.94 and PL diets which recorded 12.87 in 3\%diet. Also, there were significantly improved in DE (Kcal/ $\mathrm{kg}$ diet) with PLE diets compared to the control group.

\section{Carcass characteristics}

Effect of different treatments on some carcass traits is showed in Table 4. Results indicated that carcass (weight and percentage), Liver\%, Heart \%, Kidneys $\%$, Lungs $\%$ and dressing percentages were not significant affected with feeding on PLE and PL supplemented diets as compared to control diet. Also, there were insignificantly affected by different treatments in edible giblets (liver, heart and kidneys). Abdalla et al. (2012) and Navid, et al. (2011) concluded that dietary supplementation of $2 \%$ PL meal and papain in off-layer hens for a few days before slaughter improved meat quality in terms of meat tenderness and juiciness. Moreover Abdalla (2012) indicated that hens fed on supplemented diets with papaya leaves had significantly higher carcass and dressing percentage. Sorwar et al, (2016) also, agree with no significant effect papaya leaf in carcass traits in broiler.

Effect of different treatments on meat quality is showed in Table 5. Results indicated that Moisture, Ash \% and EE \% were not significantly affected by feeding rabbit on PLM and PL diets as compared to control diet. 
USINGPAPAYALEAVES \& THEIR EXTRACT SUPPLEMENTATION IN RABBITS 179

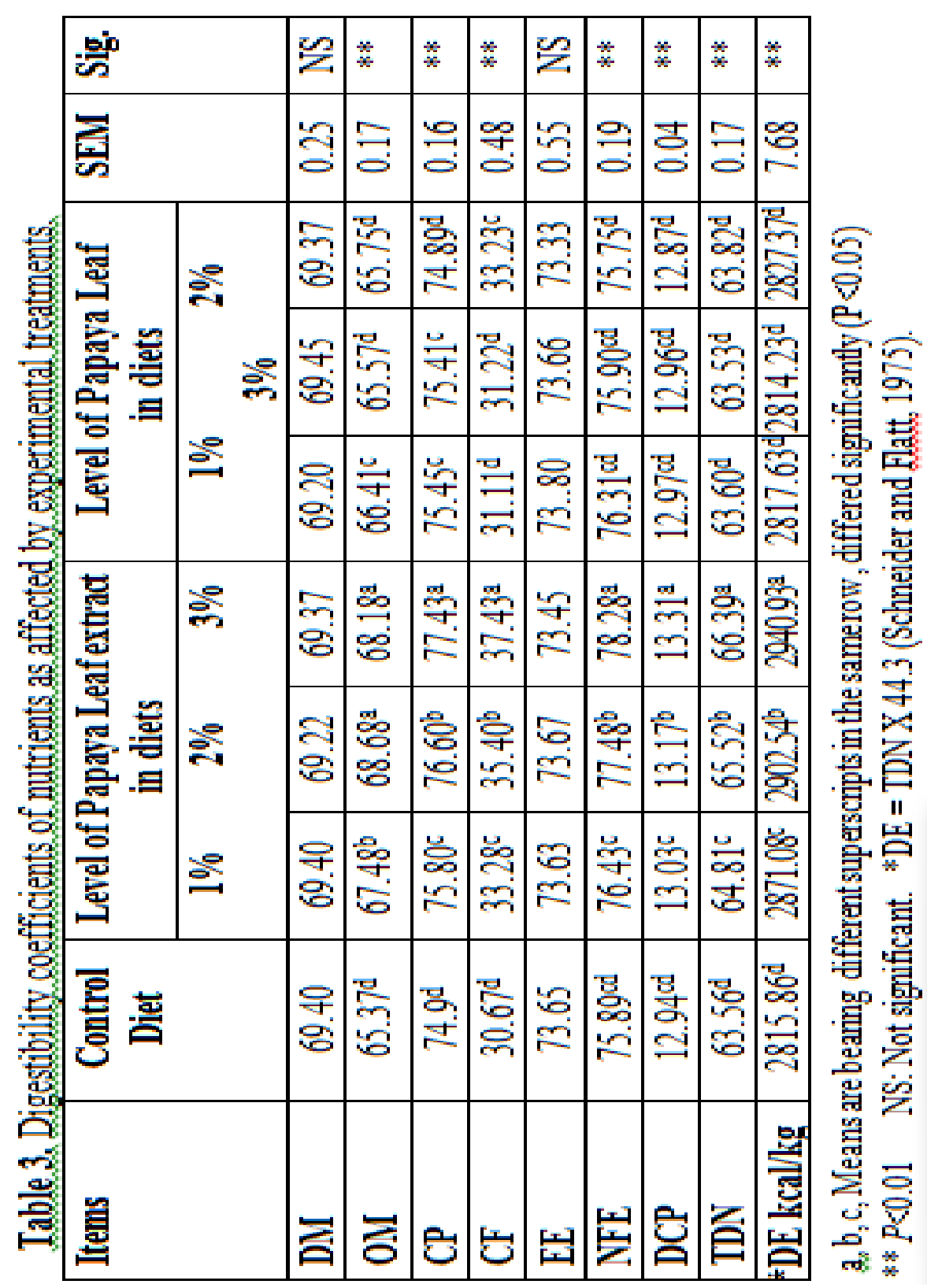



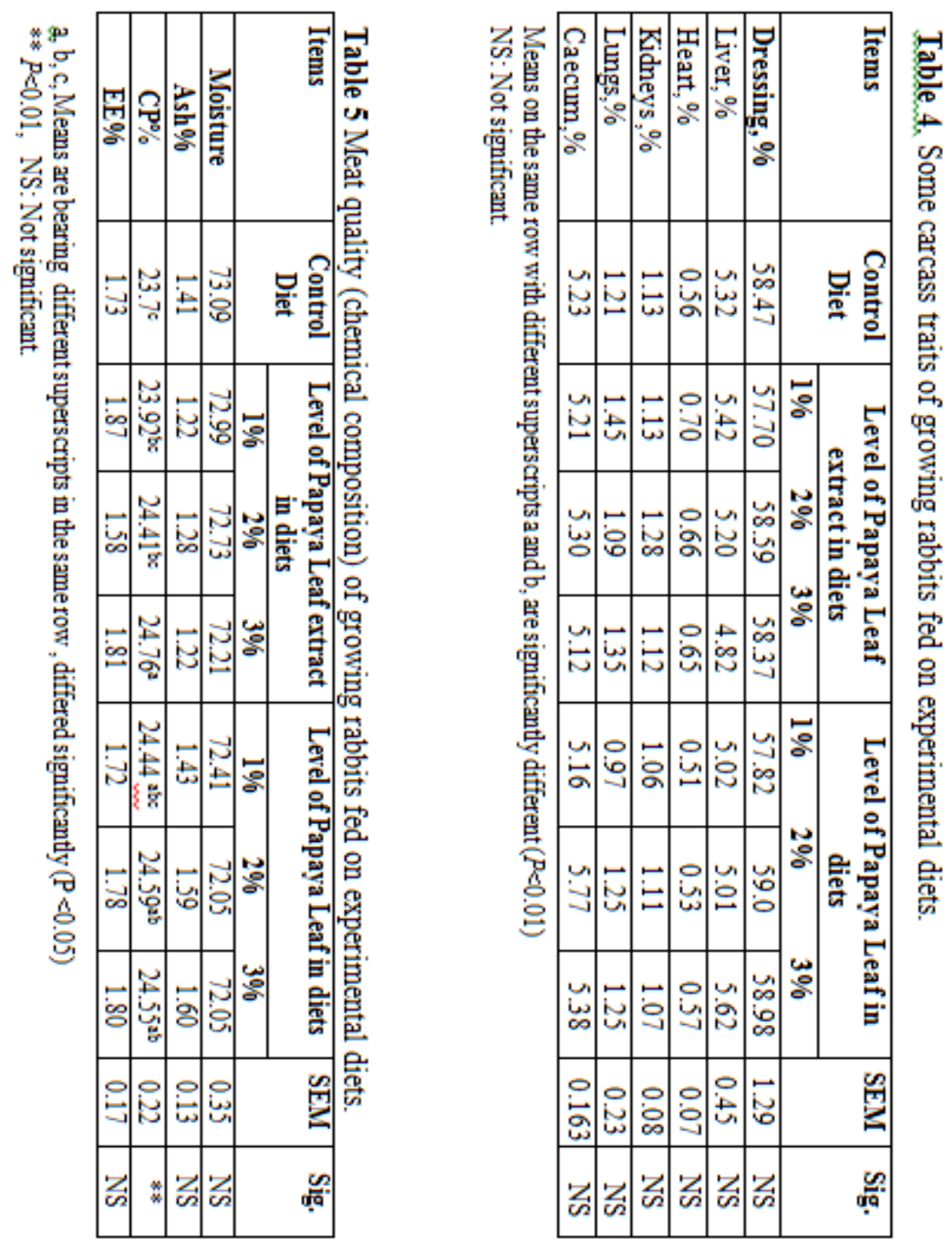
However, carcass protein was significantly $(\mathrm{P}<0.0 .01)$ affected, the highest value (24.76) was recorded for rabbit fed 3\% PL diet followed by 24.59 which recorded for $2 \%$ PLM diet comparing with rabbit fed control diet which recorded the lowest value (23.7). These results might be attributed to the effect of proteolytic enzyme found in the papaya leaves (papain enzyme) which may cause more degradation and availability of dietary protein. The increase in protein content of meat improves the nutritive value and quality of rabbit's meat. Also, this increase in meat protein in rabbits can be attributed mainly to the presence of amino acids, vitamins, increase of protein digestibility as mentioned and improving intestinal absorption and digestion of all nutrients due the stimulus to the development, proliferation and differentiation of intestinal cells. These enzymes increased of all nutrient digestibilities.

\section{Blood plasma constituents:}

Total protein, albumin and globulin were significantly increased by adding PLM or PL in diets as shown in Table 6. This increase may be due to the increase in protein synthesis, and digestion of protein. Increased globulin concentration with increased papaya inclusion which was observed in the present study may be an indication of increased immunity in rabbits since the liver will be able to synthesize enough globulins for immunologic action as mentioned by Sunmonu and Oloyede (2007). This result is agreement with ElKholy et al. (2008), Zeedan et al. (2009) and El-Neney et al. (2013 \& 2015). Lien and $\mathrm{Wu}$ (2012) found that papain supplementation markedly increased total serum globulin, total protein for laying hens.

All feed addition decreased cholesterol, LDL and total lipids compared to control diet. This result is agreement with Lien and Wu (2012) who indicated that papain supplementation reduced liver cholesterol. They added that this implies that papain affect cholesterol absorption or metabolism, indicating that papain supplementation was good for coronary health. Also they added that papain not only contains protease, but also phospholipase. Oloruntola and Ayodele (2017) reported that reduction of cholesterol level recorded may be as a result of activities of some secondary metabolites present in PL meal which exert reducing effect on cholesterol uptake in the intestine. Capability of saponin, one of the anti-nutrients present in PL in reducing absorption of cholesterol through intra-lumenal physiochemical interaction was reported by Yilkal ( 2015).

Low density lipoprotein, which is otherwise known as bad cholesterol collects in the blood vessels walls, narrows or blocks the blood vessel lumen 
and increased risk of atherosclerosis and heart disease. Therefore, reduced low density lipoprotein in rabbits due to dietary papaya leaves found in this study is

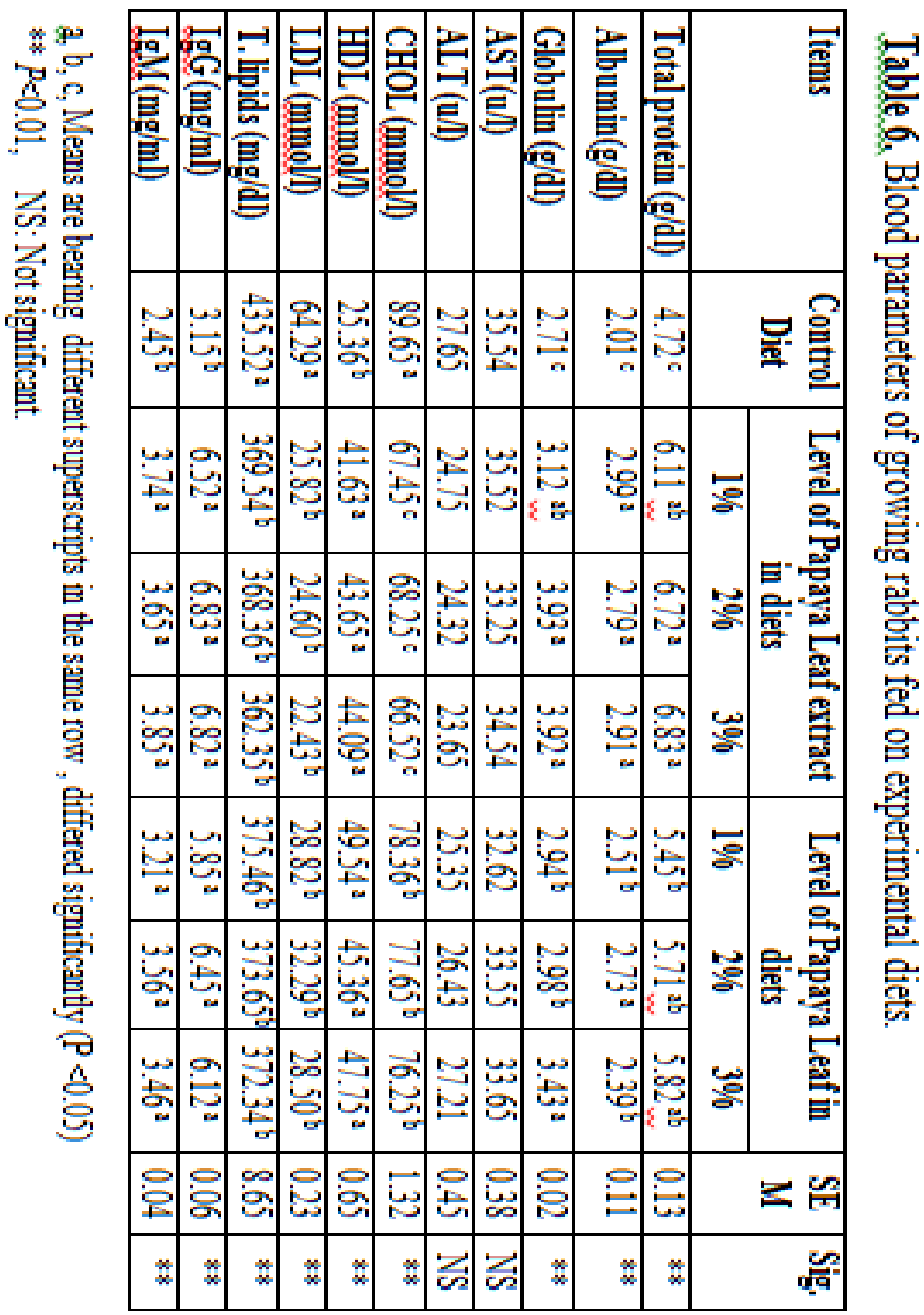


a health benefit and supports the wholesomeness of this leaf meal in rabbits' nutrition.

No significant differences $(\mathrm{P}<0.05)$ were observed in AST and ALT among treatments (Table 6). Liver function as AST and ALT activity were not affected by dietary treatments with supplementing papaya. Values AST and ALT were within the normal range and indicated that the animals were generally in a good nutritional status and their livers were in a normal health condition. These results may explain that increasing papaya leaves or its extract to $3 \%$ in rabbit diets is safe with liver functions and so it did not have any harmful effects on liver tissues. This result is in harmony with finding of El-Neney et al. (2013). On the other hand, Zeedan et al. (2009) and Lien and $\mathrm{Wu}$ (2012) reported that supplementing papaya to the diet of growing rabbits or laying hens decreased significantly $(\mathrm{P} \leq 0.05)$ of AST and ALT

Data presented in Table 6 showed that Concentrations of $\operatorname{IgG}$ and IgM in plasma were high in PLM supplemented diets, while they low in control. These results are in agreement with those obtained by El-Neney et al. (2015) Lien and $\mathrm{Wu}$ (2012) showed that papain supplementation markedly increased IgG levels. Total globulin was mainly synthesized into antibodies, implying that papain could enhance animal immunity. Rose et al. (2006) reported that papain enhanced IL-6 production dose-dependently.

The additive effects of Papaya leaves on the improvement of the immune response may be due to the increased availability amino acids, which are nutrients needed for an effective and vigorous immune response, and to the beneficial effects on the gastrointestinal microflora. Many studies have demonstrated the antibacterial and anti-fungal properties of papaya latex (Nwinyi et al., 2010 and Aravind et al., 2013). Essence of these properties in papaya latex may explain the enhancement of immune system activity. Miyamoto et al. (2004) showed that papaya enzyme increase immune system function. Lien and $\mathrm{Wu}$ (2012) found that papain could enhance animal immunity, enhance protein metabolism, ameliorate inflammation and regulate immunity.

Generally the increase in blood constituents may be due to the role of papaya leaves in improving all nutrient digestibility especially CP (Table 4). Papaya latex consists of proteolytic enzyme and may possess antimicrobial, antifungal, antioxidant and against many different parasites. This component increased from digestibility and efficiency of nutrition absorption and utilization thus may be reflected on better performance production and reproductive. Also, it may be probably led to an increase in the absorption rate from the digestive tract, thus blood constituents of the supplemented animals reflected a corresponding increase of these values. 
Higher glutathione peroxidase (GPx) $(\mathrm{P}<0.05)$, superoxide dismutase (SOD) and catalase ( CAT) activities were recorded in rabbits fed diets supplemented with papaya (Table 7) these results are agreement with Oloruntola et al., 2018, who reported that GPx and SOD were significantly improved by dietary PL. The improved GPx and SOD activities in this study further supports the earlier claim that pawpaw is rich in antioxidant nutrients (Bolu, Sola-Ojo, Olorunsanya, and Idris, 2009) and that active ingredients of plants have strong antioxidant effects such as hydrogen peroxide, nitric oxide, and superoxide neutralization by increasing the production of SOD, GPx, and CAT (Ali, Marrif, Noureldayem, Bakheit, and Blunden, 2006; Dhama et al., 2015). In addition, since oxidative stress was identified as a cause for reduce growth rate in animals (Vara Prasad Reddy, Thangavel, Leela, and Narayana Raju, 2009); the increased antioxidant enzymes in rabbits fed diet contain PLE and PL in this study may also explain the enhanced performance recorded in the rabbits.

\section{Caecum contents and Microbiological assay}

Caecum content $\mathrm{pH}$, total volatile fatty acids and ammonia concentration at the end of the study are presented in Table 8 . Analysis of variance revealed that feeding growing rabbit on PLE diets which recorded 6.43 for $3 \%$ diet and PL diets which recorded 5.80 for 3\% diet comparing with control diet which recorded 6.00 significantly $(\mathrm{P}<0.01)$ increased the value of $\mathrm{PH}$. Total volatile fatty acid was increased and unfavorable ammonia was decreased significantly with feeding on PLE diets and which recorded 5.49 and 8.17 respectively for $3 \%$ diet and PL diets which recorded 4.26 and 8.42 respectively for 3\% diet comparing with control diet which recorded 3.72 and 9.84 respectively these results may related to antimicrobial activity to papaya leaves and its extract. Microbial counts (x $1081 \mathrm{CFU} / \mathrm{ml}$ ) in caecum as affected by the experimental diets at the end of the study are presented in Table 9.

Results revealed that PLE diets and PL diets significantly $(\mathrm{P}<0.01)$ decreased the values of all studied microbes comparing with control diet except yeasts values were increased significantly $(\mathrm{P}<0.01)$ while Salmonella and Shigella were not detected in all diets. These results agree with Doughari et al., (2007), Emeruwa (1982), Leite et al.,(2005) and Mahendra and Nikhil (2016) Who reported that seeds of Carica papaya were found to possess bacteriostatic activity against several enteropathogens such as bacillus subtilis, Enterobacter cloacae, Escherichia coli, salmonella typhi, staphylococcus, protease vulgaris, pseudomonas aeruginosa and klebsiella pneumonia. Among the grampositive and gram-negative bacteria tested the gram negative bacteria were more susceptible to the extract. The latex of papaya and fluconazole has synergistic action on the inhibition of Candida albicans growth (Giordiani et al., 1997). 
USINGPAPAYALEAVES \& THEIR EXTRACT SUPPLEMENTATION IN RABBITS 185
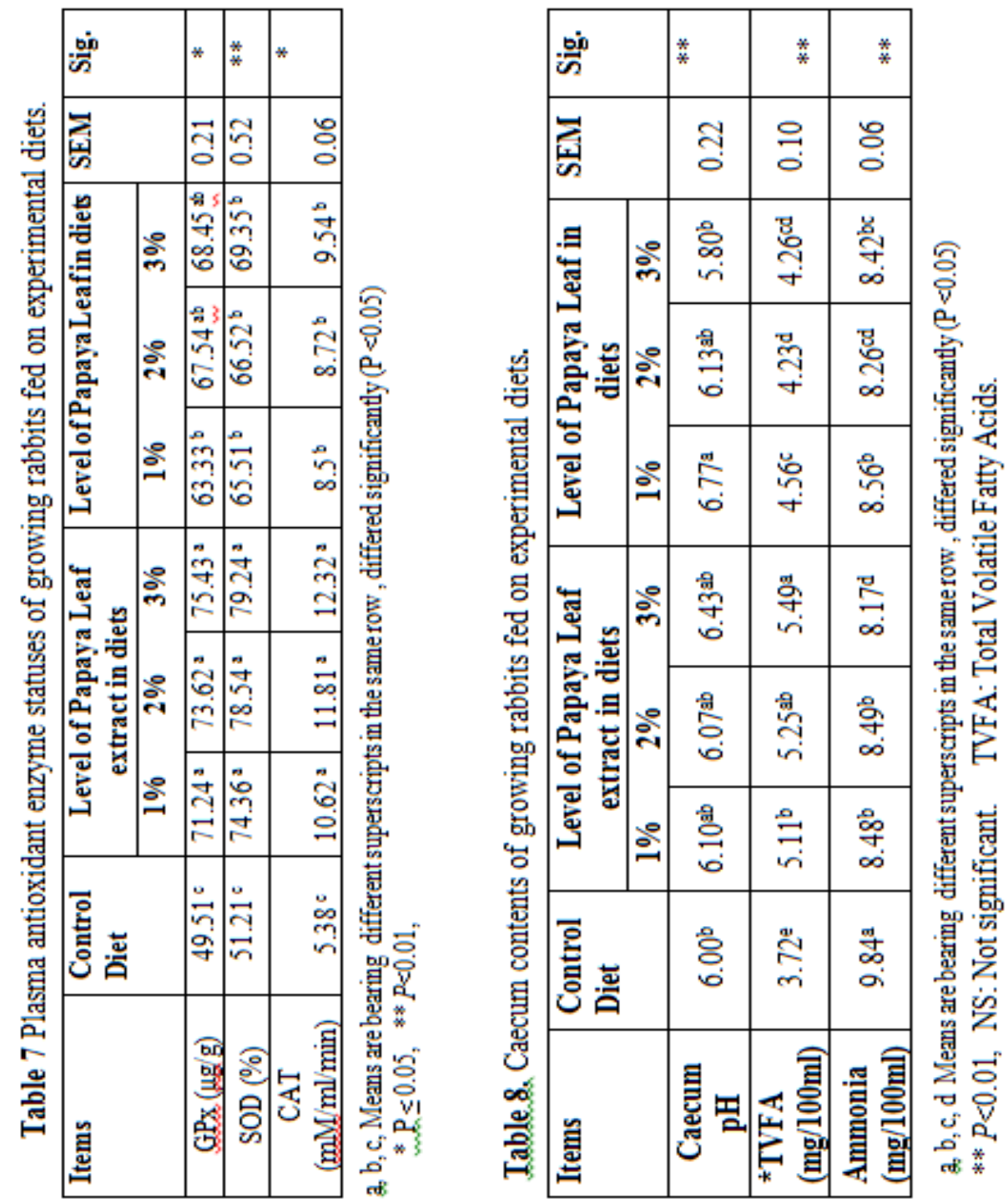


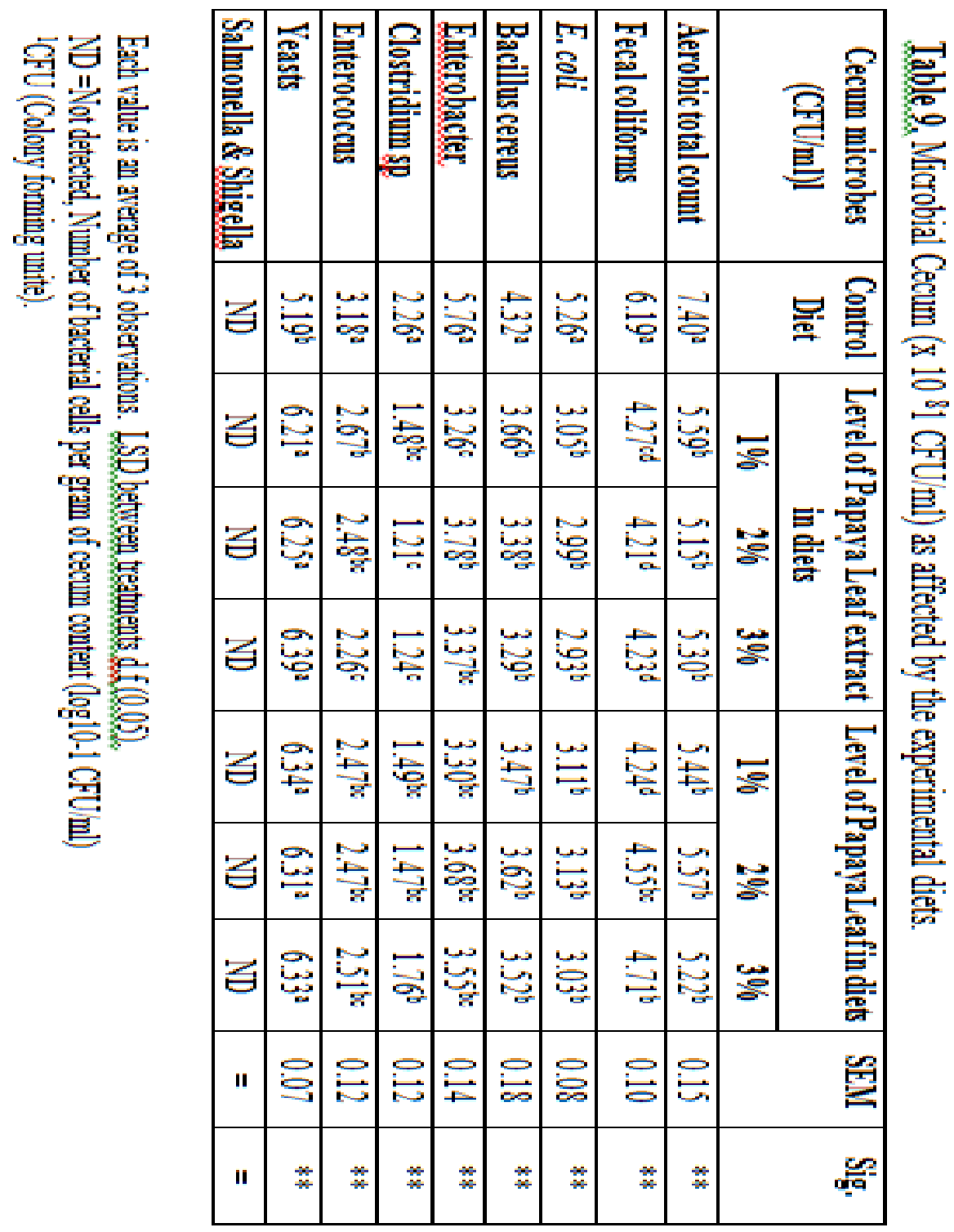




\section{USINGPAPAYALEAVES \& THEIR EXTRACT SUPPLEMENTATION IN RABBITS 187}

This synergistic effect results in partial cell wall degradation due to lack of polysaccharides constituents in the outermost layers of fungal cell wall and release of cell debris into the cell culture. Latex proteins appear to be responsible for antifungal action and minimum protein concentration for producing a complete inhibition was reported as about $138 \mathrm{mg} / \mathrm{dl}$ (Giordiani et al., 1991).

\section{Economic efficiency}

Data presented in Table 10. showed that rabbits fed on PLE supplemented diets achieved the highest economic efficiency with values 1.92 , 1.84 and 1.86 respectively followed by that fed on PL diets with values 1.86 , 1.73 and 1.70 respectively, for relative economic efficiency the highest was for 1,3\% PLE diets with values 115 and 111.38 followed by 1\% PL diet with value 111.38 followed by $2 \%$ PLE diet with value110.18 followed 1,3\% PL diets with values 103.59 and 101.02, and the least values for economic efficiency and relative economic efficiency were shown with group fed on control diet with values $(1.67,100)$ respectively. These results were agree with Sorwar et al.,(2016) and Rahman et al., (2014) who indicated that supplementation with PL was more profitable with a higher net profit $/ \mathrm{kg}$ than control group in broiler.

\section{Liver histological examinations:}

Figures 1, 2, 3, 4, 5, 6 and 7 show the histological sections of the liver. The histological hepatic cells appearances in rabbits fed control diet showing normal histological structure of hepatic tissues composed of hepatocytes disposed of in the sheet which are separated by sinusoids free of collections and inflammatory cells, moderate congestion of the portal vessels of polymorph nuclear cells (Fig. 1). No Histological change observed in the liver of rabbits treated with 1,2,and $3 \%$ PL supplementation and 1, 2, and $3 \%$ as PLE, Fig 2, $3,4,5,6,7$ compared with control group Fig1 normal hepatocytes $(\mathrm{H})$ and central vein (c).

Liver from 1\%PLE group showing normal histology; normal hepatocytes $(\mathrm{H})$ and central vein $(\mathrm{C})$, Fig 2. Liver from 2\% PLE group showing normal hepatocytes with prominent nucleus $(\mathrm{H})$ and normal central vein $(\mathrm{C})$, Fig 3 . Liver from 3\% PLE group showing normal hepatocytes with prominent nucleus $(\mathrm{H})$, dilated blood sinusoids (arrows), and normal central vein $(\mathrm{C})$, Fig 4. Liver from $1 \% \mathrm{PL}$ group showing normal hepatocytes with distinct nucleus and prominent nucleolus (arrows), dilated blood sinusoids, and normal central vein (C), Fig 5. Liver from 2\% PL group showing normal histology; normal hepatocytes $(\mathrm{H})$ and central vein Fig 6. Liver from 3\% PL group showing normal hepatocytes with distinct nucleus and prominent nucleolus (arrows), dilated blood sinusoids, and normal central vein (C), Figure7. 


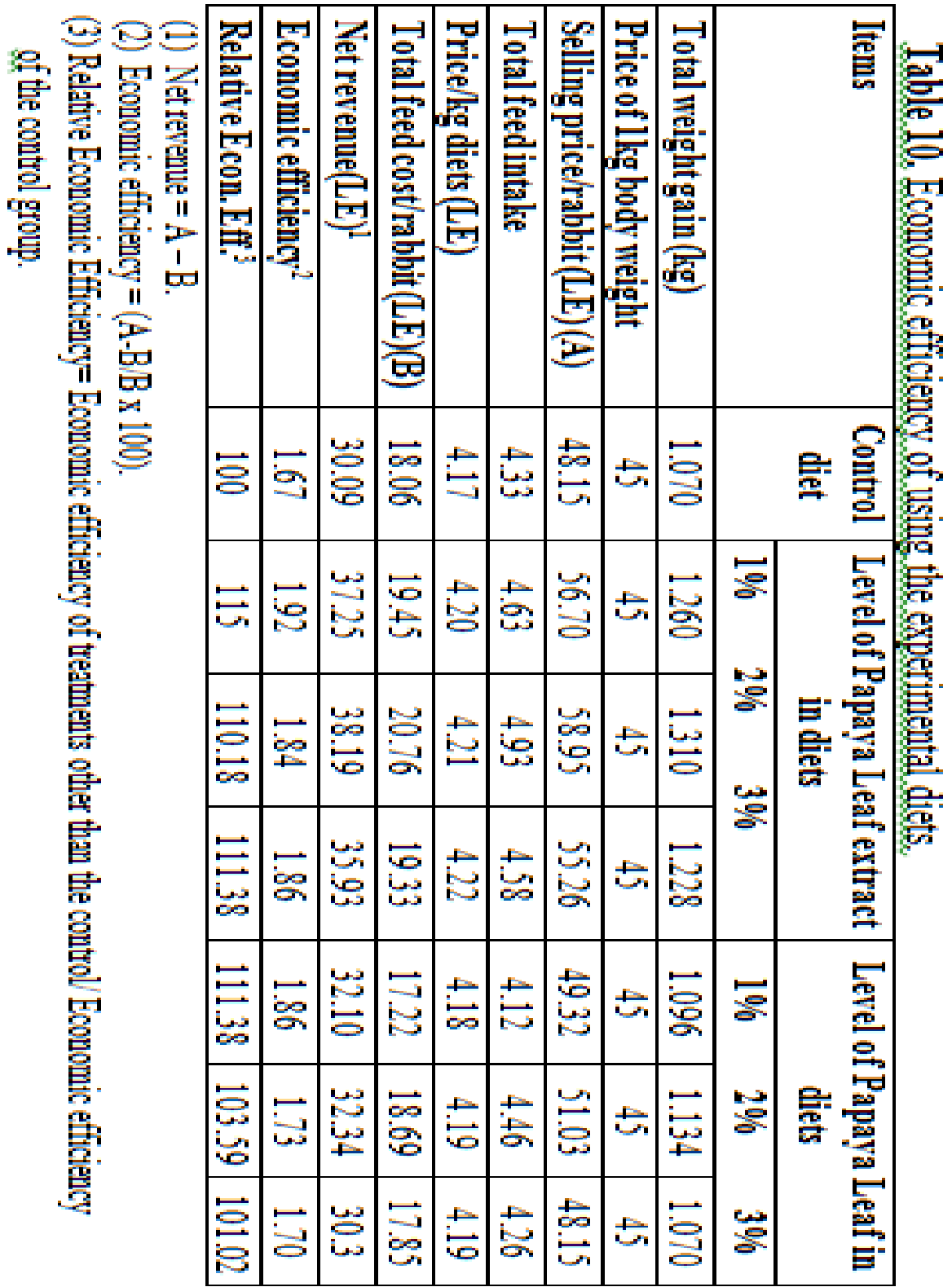


USINGPAPAYALEAVES \& THEIR EXTRACT SUPPLEMENTATION IN RABBITS 189

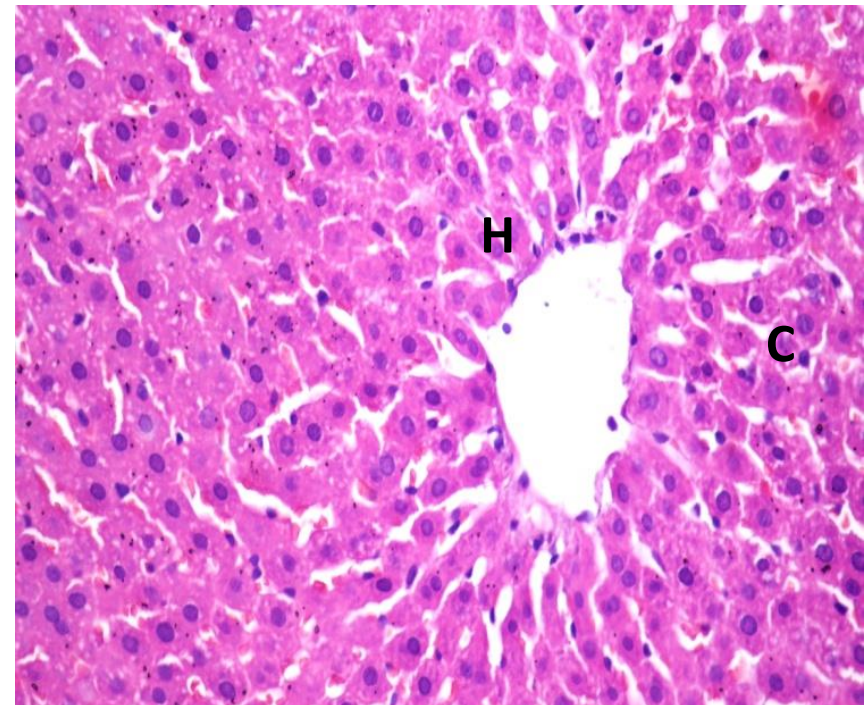

Fig. 1. .Liver from control group showing normal histology; note the normal hepatocytes $(\mathrm{H})$ and central vein (c), (HE X400).

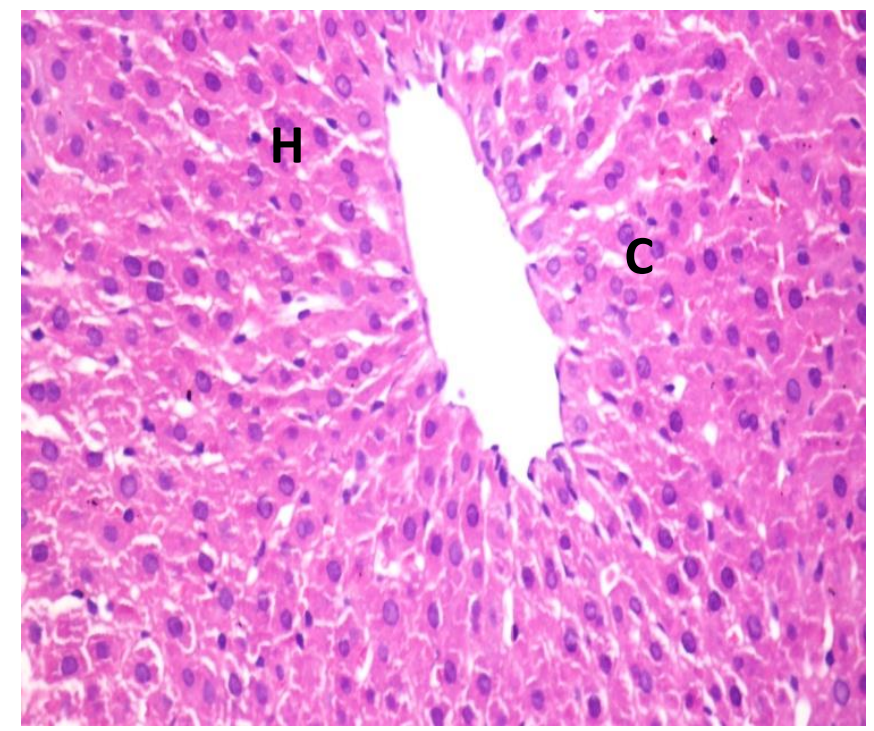

Fig. 2. Liver from 1\%PLE group showing normal histology; note the normal hepatocytes $(\mathrm{H})$ and central vein $(\mathrm{C}),(\mathrm{HE} \mathrm{X} 400)$. 


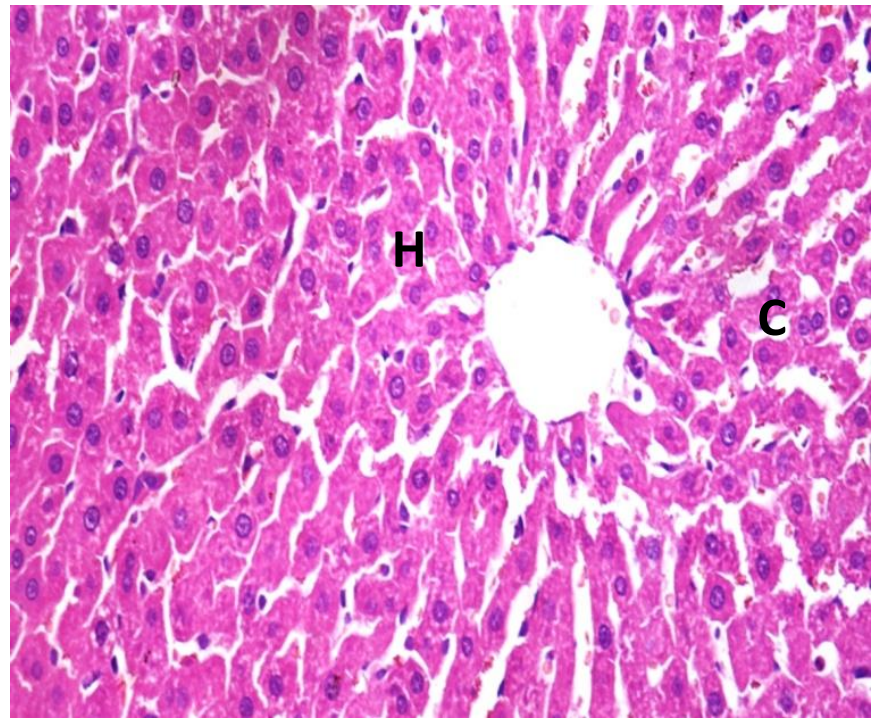

Fig. 3. Liver from $2 \%$ PLE group showing normal hepatocytes with prominent nucleus $(\mathrm{H})$ and normal central vein $(\mathrm{C})$, (HE X400).

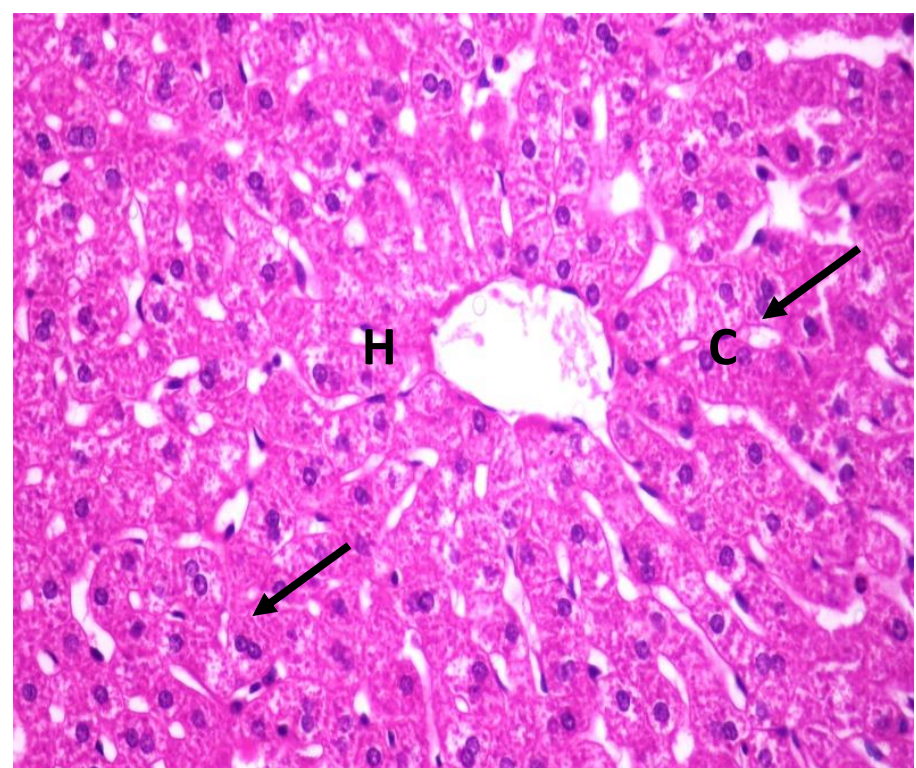

Fig. 4. Liver from 3\% PLE group showing normal hepatocytes with prominent nucleus $(\mathrm{H})$, dilated blood sinusoids (arrows), and normal central vein $(\mathrm{C})$, (HE X400). 
USINGPAPAYALEAVES \& THEIREXTRACT SUPPLEMENTATION IN RABBITS 191

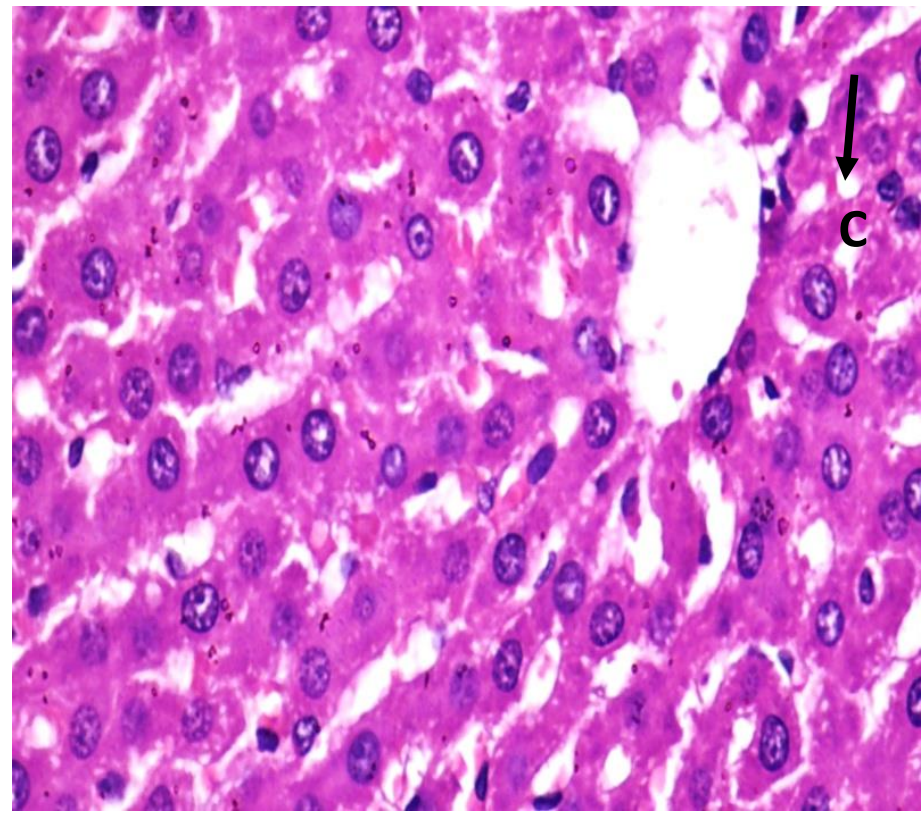

Fig. 5. Liver from 1\% PL group showing normal hepatocytes with distinct nucleus and prominent nucleolus (arrows), dilated blood sinusoids, and normal central vein (C), (HE X400).

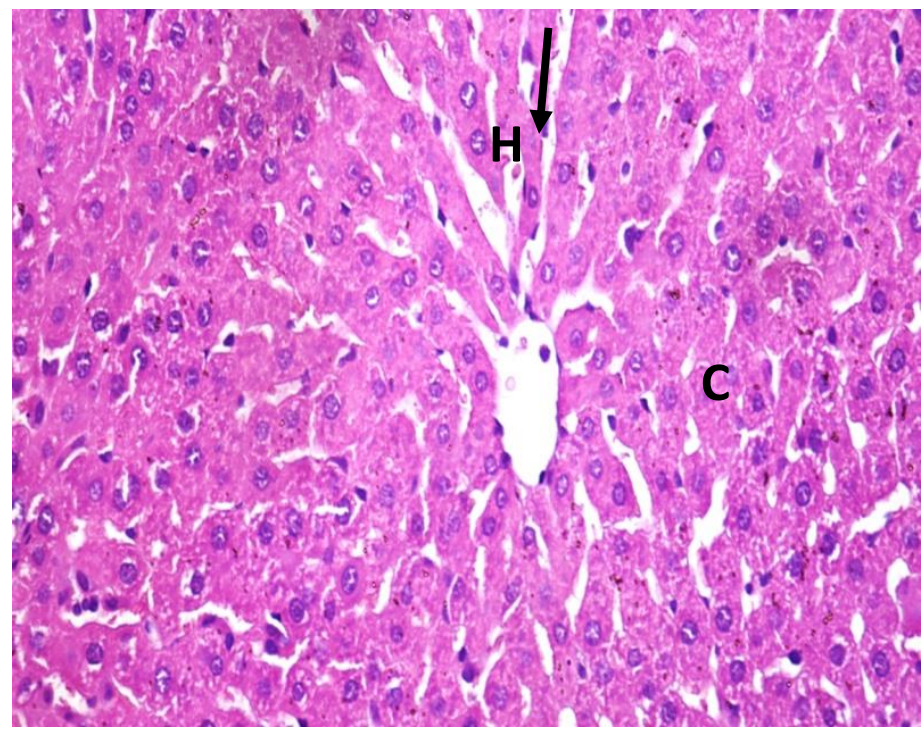

Fig. 6. Liver from 2\% PL group showing normal histology; note the normal hepatocytes $(\mathrm{H})$ and central vein $(\mathrm{C}),(\mathrm{HE} \mathrm{X} 400)$. 


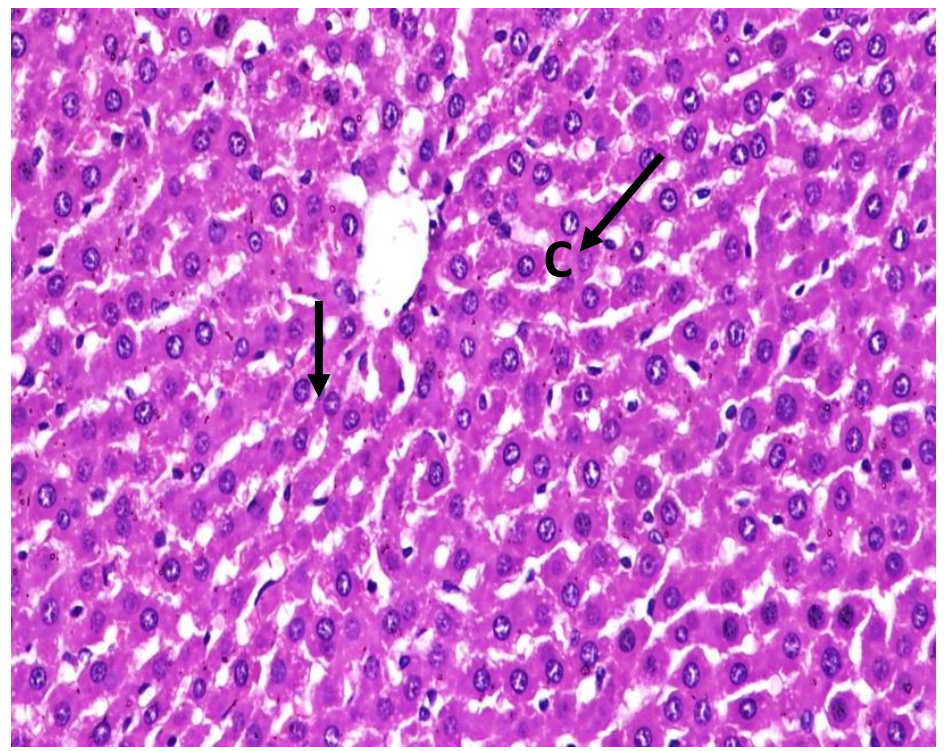

Fig. 7. Liver from 3\%PL group showing normal hepatocytes with distinct nucleus and prominent nucleolus (arrows), dilated blood sinusoids, and normal central vein (C), (HE X400).

Conclusively, supplementation growing rabbit diet by 3\% PLE improved the performance, crude protein, digestibility, immunity and the antioxidant enzyme status.

\section{REFERENCES}

A.O.A.C. (1998). Association of Official Analytical Chemists, Official methods of analysis. $15^{\text {th }}$ Edition, Published by the AOAC, Washington, D. C., USA

A.O.A.C. (2000). Official Methods of Analysis $16^{\text {th }}$ ed. Association of Official Analytical Chemists. Washington, DC., USA.

Abdalla, H. O., Ali N. N. A. Siddig., F. S and S. A. M. Ali (2012). Improving Tenderness of Spent Layer Hens Meat Using Papaya Leaves (Carica papaya). Pak Vet J, 33(1): 73-76.

Agriculture Ministry Decree (1996). The Standard Properties For Ingredients, Feed Additives And Feed Manufactured For Animal And Poultry. El-Wakaee El-Masria, No. 192 (1997), P 95 Amirria Press Cairo, Egypt. 
Ahmad S (2005). Comparative efficiency of garlic, Papaya leaf and kalongi as growth promoter in broiler. M.Sc. (Hons.) Thesis, Department Poultry Sciences, University of Agriculture, Faisalabad, Pakistan.

Ali, B. H., Marrif, H., Noureldayem, S. A., Bakheit, A. O., \& Blunden, G. (2006). Some biological properties of curcumin: A review. Natural Product Communication, 1: 509-521.

Aravind, G.; Debjit Bhowmik, Duraivel, S. and Harish, G. (2013). Traditional and medicinal uses of carica papaya. J. of Med. Plants, 1(7): 1-15.

Baired Parker (1962) An improved diagnostic and selective medium for isolating coagulase positive staphylococci, Journal of Applied Microbiology, 25(1):12 - 19.

Bancroft TD, Stevens A, Turner DR (1996). Theory And Practice of Histological Technique, $4^{\text {th }}$ ed. Churchill, Livingstone, New York

Battaa, A. M. El-Neney, Nasra B. Awadien and T. A. Ebeid (2015). The productive performance and immunological traits of local chickens strain by using natural enzymes (Plant Papain) and remnants of plant Papaya. 1- Effect of Papaya latex on lying period. Egypt. Poult. Sci., Vol 35 (I): $1-24$.

Bolu, S. A. O., Sola-Ojo, F. E., Olorunsanya, O. A., \& Idris, K. (2009). Effect of graded level of dried pawpaw (Carica papaya) seed on the performance, haematology, serum biochemistry and carcass evaluation of chicken broilers. International Journal of Poultry Science, 8(9), 905-909.

Bou, R., Codony, R., Tres, A., Decker, E. R., and Guardiola, F. (2009) Dietary strategies to improve nutritional value, oxidative stability, and sensory properties of poultry products, Crit. Rev. Food Sci., 49: 800-822.

Burkill HM (1985). The Useful Plants Of West Tropical Africa. Royal Botanic Garden, Kew, UK. Volume 3.

Cheeke, P.R. (1987). Rabbit Feeding and Nutrition. Academic Press. Orlando, Florida, USA.

Cheeke, P.R.; N. Patton and G.S. Templton (1982). Rabbit Production.5th Edition. The Intersate Printers and Publishers DanvilleII. Conway, E.J. (1958). Micro-diffusion analysis and volumetric error (4th Ed.) The McMillan Co., New York.

Conway, E.J. (1958). Micro-Diffusion Analysis And Volumetric Error. $4 \mathrm{t}^{h}$ Ed. The McMillan Co., New York

Dhama, K., Latheef, S. K., Mani, S., Samad, H. A., Karthik, K., Tiwari, R., Tufarelli, V. (2015). Multiple beneficial applications and modes of action of herbs in poultry health and production - a review. International Journal of Pharmacology, 11(3): 152-176. 
Difco Laboratories Incorporated (1989). Difco Manual Of Dehydrated Culture Media And Reagents For The Microbiology. Difco Lab., Detroit, Michigan, USA.

Doughari Jh, Elmahmood AM, Manzara S.(2007). Studies on the antibacterial activity of root extracts of Carica papaya L. Afr. J Microbiol. Res.; 37-41.

Duncan, D.B. (1955). Multiple ranges and multiple F-Test. Biometrics 11:42.

Eadie, J.M.; P.N. Hobson and S.O. Mann (1967). A note on some comparisons between the rumen content of barley fed steers and that of young calves also fed on high concentrate rations. J. Anim Prod., 9: 247.

El Moussaoui A, M Nijs, C Paul, R Winljens, J Vincentelli, M Azarkan and Y Looze, (2001). Revisiting the enzymes stored in the laticifers of Carica papaya in the context of their possible participation in the plant defence mechanism. Cell Mol Life Sci, 85: 556-570.

El-Kholy, K. H.; Zeedan, K. ; I. El-Neney; Battaa A.; M. Zeedan;Omyma, I. and Abd El-Hakim, A.S. (2008). Study on the optimal crude papaya latex content of growing rabbit diet under summer conditions: Effects on growth performance and immune status. Inte. J. of Poultry Sci., 7: 978-983.

El-Neney, Battaa, A. M., Abd El-Hakim, A. S., El-Kholy, K. H. and Zeedan, Kh. I. I.(2013). Effect of crude papaya (Carica papaya) latex supplementation to low protein diets on productive performance, digestion, immune system, activity of certain digestive enzymes and intestinal morphology of growing rabbits. Egypt. Poult. Sci., 33: 729-750.

Emeruwa AC. (1982) Antibacterial substance from Carica papaya fruit extract. J Nat Prod., 45(2):123-127

Feed Composition Tables for Animal and Poultry Feedstuff Used in Egypt (2001). Technical bulletin No.1, Central Lab for Feed and Food; Ministry of Agriculture, Egypt.

Giordiani R, Siepaio M, Moulin TJ, Regli P. (1991). Antifungal action of Carica papaya latex, isolation of fungal cell wall hydrolyzing enzymes, Mycoses. 34 (11-12):467- 477.

Giordiani R, Gachon C, Moulin TJ, Regli P. (1997). A synergistic effect of Carica papaya latex sap and fluconazole on Candida albicans growth. Mycoses.40 (11-12):429- 437.

Kim, H.U. and J.M. Goepfert (1971). Enumeration and identification of Bacillus cereus in foods, 1, 24-hours presumptive test edium. Appl. Microbiol. 22: 581-587.

Lansdown, A.B. (2006). Silver in health care: antimicrobial effects and safety in use. Current Problems in Dermatology, 33: 17-34. 
Laudadio, V.;Ceci, E. W.; Lastella, N. M., and Tufarelli, V.(2015). Dietary high-pliphenols extra-virgin olive oil is effective in reducing cholesterol content in eggs, Lipids Health Dis., 14, 7 pp., doi:10.1186/s12944-0150001-x, 0015.

Leite AA; Nardi RM; Nicoli JR; Chartone SE; Nascimento AM. (2005). Carica papaya seed macerate as inhibitor of conjugative $\mathrm{R}$ plasmid transfer from Salmonella typhimurium to E.coli, in vitro and in the digestive tract of genobiotic mice. J. Gen Appl. Microbiol.; 51(1):21-26

Lien, T. F. and Wu, C. P. (2012). Effects of supplemental papain on egg production and quality, serum and liver traits of laying hens. J. Anim. Prod. Adv., 2(7): 310-315.

Lodder, J. (1952). The yeasts. 1st Ed. Pup. Inc., N.Y. Mahendra C. Gunde and Nikhil D. Amnerkar (2016). Nutritional, medicinal and pharmacological properties of papaya (Carica papaya linn.): A review. Journal of Innovations in Pharmaceuticals and Biological Sciences (JIPBS), Vol. 3 (1): 162-169.

Meraj M S (1998). Comparative effect of using neem, nishyindha and papaya on growth promoter in broiler chickens. Annals of Biological Research 2: 373-378.

Miyamoto, D., Watanabe, J. and Ishihara, K. (2004). Effect of water-soluble phospholipids polymers conjugated with papain on the enzymatic stability. Biomaterials, 25:71-76.

MollaM R;Rahman MM; Akter F and Mostofa M (2012). Effects of papaya leaf, cinnamon and black pepper as growth promoters in broilers. The Bangladesh Veterinarian 29: 69-77.

Mrinal Saraf and Bhushan Kavimandan (2017). Animal Trials of Carica Papaya Leaf Extracts for Increasing Platelet Count. Indian Journal of Public Health Research \& Development, October-December 2017, Vol.8, No. 4.

Navid, S.; Sheikhlar, A. and Kaveh, K. (2011).Influence of the combination of vitamin $\mathrm{D}$ and papaya leaf on meat quality of spent layer hen. Agric. J. , 6:197-200.

North, M. O. (1981). Commercial Chicken Production. Annual. 2nd Edition, Production $6^{\text {th }}$ Ed. Interstate Printers and Publishers. INC., USA.

Nusrat M.; Mahbub M.; Fatema A.; Shobhan D.and Morshedul A.(2015). Effects of Neem, turmeric and papaya leaf extract mixture on growth performance of broilers. International Journal of Natural and Social Sciences 2 (2015) 17-21. 
Nwinyi, Chukwuemeka O. and Anthonia, A. B. (2010). Antifungal effects of pawpaw seed extracts and papain on post harvest Carica papaya L. fruit rot. Afr. J. Agric. Res. 5(12): 1531-1535.

Oloruntola O. D. and S. O. Ayodele (2017) Pawpaw Leaf Meal and Exoenzyme in Rabbit Diet: Effect on Hematological and Serum Biochemical Indices. Asian Journal of Advances in Agricultural Research, 2(4): 1-8.

Oloruntola O.D; Ayodele SO and Oloruntola DA (2018a) Effect of pawpaw (Caricapapaya) leaf meal and dietary enzymes on broiler performance, digestibility, carcass, and blood composition. Rev Elev Med Vet Pays Trop 71:3.https://doi.org/10.19182/remvt

Oloruntola O. D.; S. O. Ayodele; S. A. Adeyeye; M. H. Ogunsipe; O. T. Daramola and E. S. Ayedun (2018b). Effect of pawpaw leaf meal and multienzyme supplementation in the diet on performance, digestibility, and oxidative enzyme status of rabbits. The Journal of Basic and Applied Zoology (2018) 79:26

Oloruntola DA; Dada EO, Osho IB and Ogundolie O O (2017) Effects of hydroethanolic leaf extract of Tithonia diversifolia on parasitaemia level, serum metabolites and histopathology of organs in Swiss Albino mice infected with Plasmodium berghei NK65. Asian J Med. Health, 6(2):1-7

Onyimonyi, A.E. and E. Onu, (2009). An assessment of paw-paw leaf meal as protein ingredient for finishing broiler, Intern. J. Poultry Sci., 8(10) (2009), 995-998.

Onyimonyi, A.E; O. Adeyemi and G.C. Okeke,(2009) Performance and economic characteristics of broilers fed varying dietary levels of neem leaf meal (Azadirachta indica), Int. J. Poult. Sci., 8(2009): 256-259.

Poulter ANH and Caygil JC (1985). Production and utilization of papain-a proteolytic enzyme from Carica papaya L. Tropical Science, 25: 123137.

Rahman SM. Mostofa MN, Fatema MA, Latif and Afrin S (2014). Effects of papaya leaf leaves, papaya leaf and cinnamon extract as a growth promoter in broilers. Bangladesh Research Publications Journals, 10: 07-13.

Rose, B., Herde,r C., Löffler, H., Meierhoff, G., Schloot N.C., Walz M. and Martin, S. (2006). Dose-dependent induction of IL-6 by plant-derived proteases in vitro. Clin. Exp. Immunol., 143:85-92.

Rossi, R., Pastorelli, G., Cannata, S., Tavaniello, S., Maiorano, G., and Corino, C.(2013) Effect of long-term dietary supplementation with plant extract on carcass characteristics meat quality and oxidative stability in pork, Meat Sci., 95, 542-548.

SAS (2001). SAS user's Guide: Statistics, SAS Institute, Inc, cray .N.C. 
Schneider, B.H. and W.P. Flatt (1975). The Evaluation Of Feed Through Digestibility Experiments. University of Georgia Press Athens, Georgia, USA.423p.

Sorwar, M. G; M. Mostofa;, M. N. Hasan; M. Billah; and M. T. Rahman.(2016). Effect of kalo Jeera Seeds and Papaya Leaf Supplementation on the Performance of Broiler, Bangl. J. Vet. Med. , 14 (1): $37-42$

Steven, W.D., W.D. Hohenboken, P.R. Cheeke, N.M. Patton and W.H. Kennick (1981). Carcass and meat characteristic of Flemish Giant and New Zealand White purebred and terminal cross rabbits. Journal Applied Rabbit Research, 4: 66.

Sunmonu, T. O. and Oloyede, O. B. (2007). Biochemical assessment of the effects of crude oil contaminated catfish (Clarias gariepinus) on the hepatocytes and performance of rat. African J. Biochemistry Res. 1: 83-89.

Unigwe, C.R.; Okorafor, U.P.; Ogbu, U.M. and Nwufoh, O.C.(2014). The nutritive profile of sun-dried paw-paw (carica papaya) leaf meal and its effect on the growth performance of broiler chickens. Int. J. Pure Appl. Sci. Technol., 20 (2): 72-78.

Vara Prasad Reddy; L. S. S., Thangavel; A., Leela, V., \& Narayana Raju, K. V. S. (2009). Antioxidant enzyme status in broilers: Role of dietary supplementation of Tulasi (Ocimum sanctum) and selenium. Tamilnada Journal of Veterinary and Animal Science, 5(6), 251-256.

Wanker AK; Shirvate RN; Bahiram KB; Dhenge SA and Jasutkar RA (2009). Effect of neem (Azadirachta indica) leaf powder supplementation on growth in broilers. Veterinary World , 2(10):396-397.

Yilkal T. (2015). Important anti-nutritional substances and inherent toxicants of feeds. Food Sci. Quality Man.; 36:40-47.

Zeedan, Kh. I. ; I. El-Neney; Battaa A. M.; Abd El-Hakim A. S. and ElKholy K. H. (2009). Effect of crude papaya latex supplementation on some production, digestion and reproduction traits of rabbits. $5^{\text {th }}$ World Poultry Conference 10-13 March 2009, Taba, Egypt. 
تاثير اضافة اوراق الباباظو مستخلص اوراق الباباظ على الاداء الانتاجى الإئ

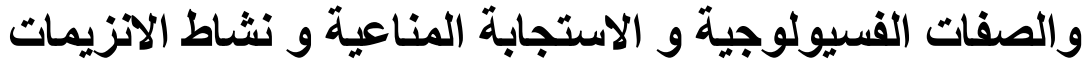
المضادة للاكسدة فى الارانب النامية

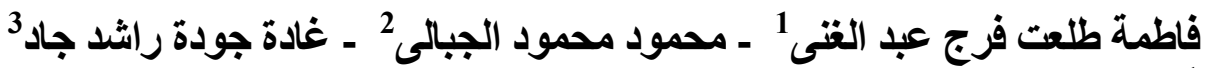

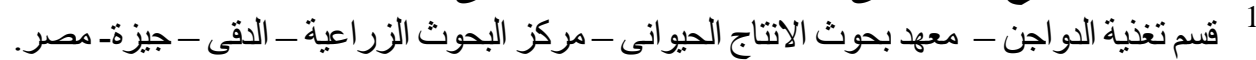

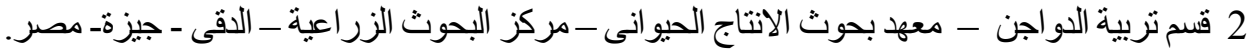
3 قسم انتاج اللو اجن - كلية الزراعة - جامعة عين شمس - مصر.

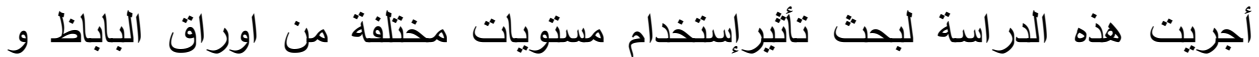

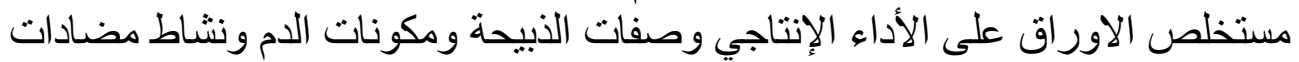

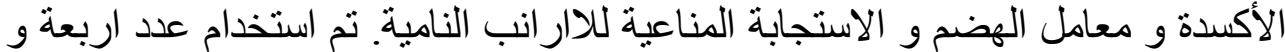

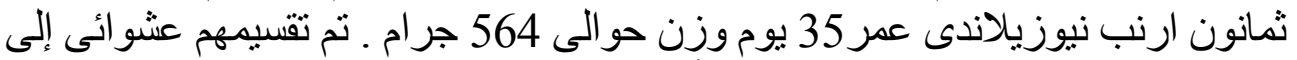

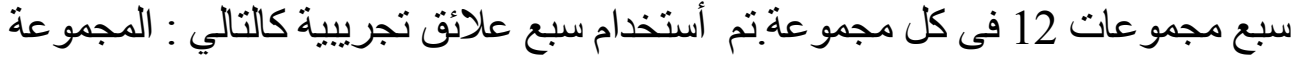

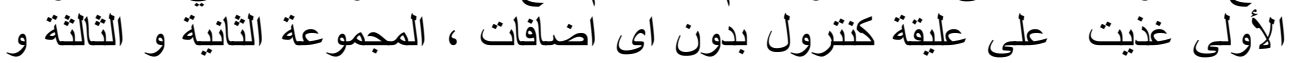

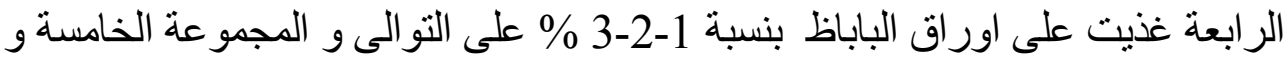

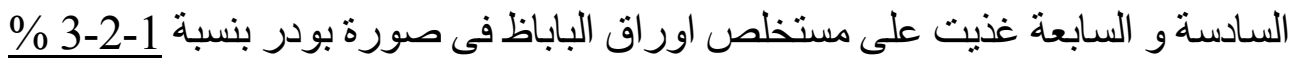

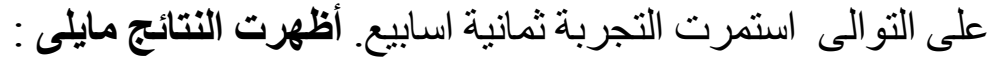

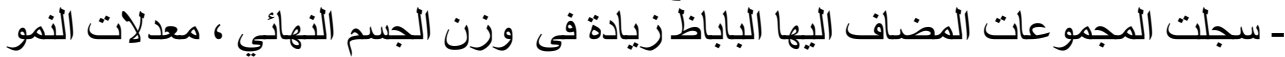
و تحسن فى كفاءة التحويل الغذائي عن الكنترول. ـ تحسنت معنويا قيم معاملات هضم المو اد الغذائيه للعلائق المضاف اليهاالباباظ بالمقارنة

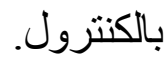

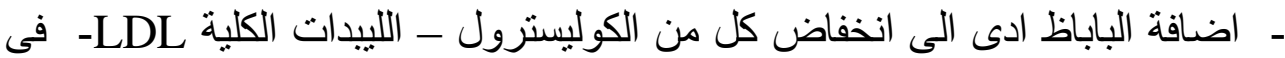

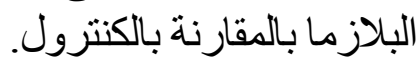

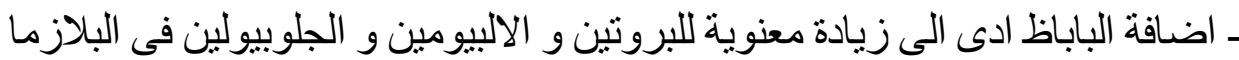

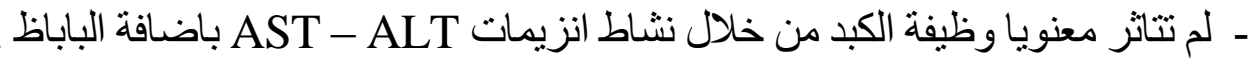

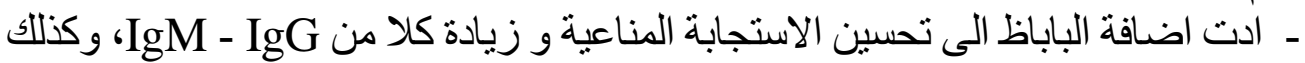

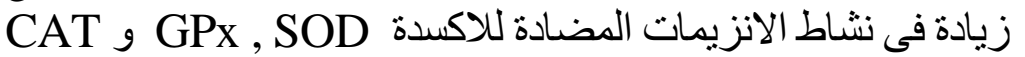

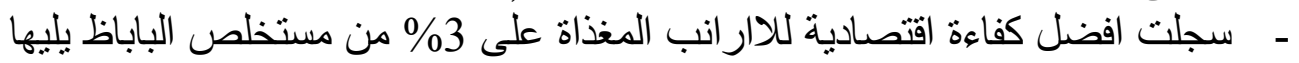

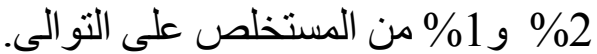

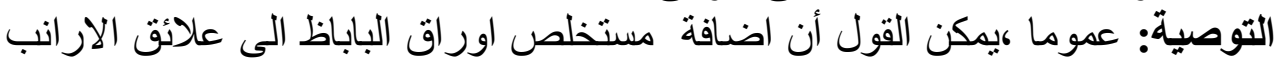

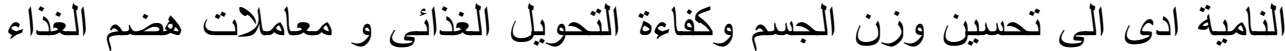
و المناعة وتحسين الكفاءة الاقتصادية . لحنية 